\title{
LACTATE LEVEL AS A PREDICTION FACTOR OF REPERFORATION AFTER REPAIRING GASTRIC PERFORATION
}

\author{
Vicky Sumarki Budipramana \\ Departement of Surgery, Faculty of Medicine, Universitas Airlangga, Dr. Soetomo Hospital, Surabaya, Indonesia
}

\section{ABSTRACT}

Reperforation after gastric perforation repair is a complication which increases the rate of morbidity and mortality in gastric perforation. The lack of ability of the tissue to use oxygen in septic condition causes anaerobic cellular metabolism and furthermore it will cause failure in closing the perforation. The production of anaerobic metabolism is lactic acid which can be measured from the blood. The aim of this study is to determine the cut-off point of blood lactate level as a predictor of reperforation after repairing gastric perforation. Forty-six patients diagnosed as gastric perforation, who were repaired in Dr Soetomo Hospital from October 2014 to October 2015 were recruited as samples. Serum lactate was taken one hour before repairing the perforation. After being repaired, the patients were observed until the 14th day to evaluate whether any reperforation would occur or not. The design of this research was cross-sectional, analytic observational. The data was analyzed using independent $t$-test and ROC for obtaining the cut-off point as a predictor of the reperforation after the gastric perforation was repaired. There was a significant difference in the mean of lactate level in the group with reperforation compared with that of the non-reperforation group, that is as big as $3.74 \pm 0.59 \mathrm{mmol} / \mathrm{L}$ and $2.60 \pm 0.76 \mathrm{mmol} / \mathrm{L}$. Using ROC curve analysis, there was the cut-off point of lactate level for reperforation $3.35 \mathrm{mmol} / \mathrm{L}$, with sensitivity $92.9 \%$, specificity $84.4 \%$, positive predictive value $72 \%$ and negative predictive Value $96.4 \%$, accuracy $87.0 \%$ and in the AUC value 0.902.

Keyword: Lactate; reperforation of gastric repair; cut-off point

\section{ABSTRAK}

Reperforation setelah perbaikan perforasi lambung adalah komplikasi yang meningkatkan tingkat morbiditas dan mortalitas pada perforasi lambung. Kurangnya kemampuan jaringan untuk menggunakan oksigen dalam kondisi septik menyebabkan metabolisme seluler anaerob dan selanjutnya akan menyebabkan kegagalan dalam menutup perforasi. Produksi metabolisme anaerob adalah asam laktat yang dapat diukur dari darah. Tujuan dari penelitian ini adalah untuk menentukan titik batas level laktat darah sebagai prediktor reperforasi setelah memperbaiki perforasi lambung. Empat puluh enam pasien yang didiagnosis sebagai perforasi lambung, yang diperbaiki di Rumah Sakit Dr Soetomo dari Oktober 2014 hingga Oktober 2015 direkrut sebagai sampel. Serum laktat diambil satu jam sebelum memperbaiki perforasi. Setelah diperbaiki, pasien diamati sampai hari ke-14 untuk mengevaluasi apakah akan terjadi reperforasi atau tidak. Desain penelitian ini adalah cross-sectional, analitik observasional. Data dianalisis menggunakan independent t-test dan ROC untuk mendapatkan cut-off point sebagai prediktor reperforation setelah perforasi lambung diperbaiki. Ada perbedaan yang signifikan dalam rata-rata tingkat laktat dalam kelompok dengan reperforation dibandingkan dengan yang dari kelompok non-reperforation, yaitu sebesar 3,74 $\pm 0,59 \mathrm{mmol} / \mathrm{L}$ dan 2,60 \pm 0,76 mmol/L. Menggunakan analisis kurva ROC, ada titik cut-off level laktat untuk reperforation 3,35 mmol/L, dengan sensitivitas $92,9 \%$, spesifisitas $84,4 \%$, nilai prediksi positif $72 \%$ dan nilai prediksi negatif 96,4\%, akurasi $87,0 \%$ dan dalam AUC nilai 0,902 .

Kata kunci: Laktat; reperforasi perbaikan lambung; titik batas

Correspondence: Vicky Sumarki Budipramana, Jl. Manyar Tirtoasri I/12 Surabaya 60117, Indonesia. Phone: (+62)811315812. E-mail: vickysbudi@gmail.com

pISSN:2355-8393 • eISSN: 2599-056x • doi: http://dx.doi.org/10.20473/fmi.v55i1.12556

- Fol Med Indones. 2019;55:43-47 • Received 10 Dec $2018 \bullet$ Accepted 21 Feb 2019

- Open access under CC-BY-NC-SA license • Available at https://e-journal.unair.ac.id/FMI/

\section{INTRODUCTION}

Reperforation after gastric perforation repair is a complication which increases the rate of morbidity and mortality in generalized peritonitis patients caused by gastric perforation. The mortality rate is $27 \%$ when there is no reperforation after repair (Hemmat \& Alireza 2011), however the mortality rate will increase another 29.4\% higher if it is reperforated (Moller \& Hylander 2008). This condition is caused by the leakage of gastric content into the peritoneal cavity and it will followed by generalized peritonitis, sepsis and septic shock 
eventually (Hyman et al 2009, Wagner \& Egger 2003). It needs an objective parameter as a predictor to determine the cut-off point for the possibility of reperforation after repairing gastric perforation. In septic condition there is a defect in cellular oxygen utilization, anaerobic metabolism occur and blood lactate level will increase as a result. The anaerob condition in the tissue causes disruption in the tissue regeneration after repairing gastric perforation and as the result, it will cause reperforation (Chung \& Vishalkumar 2017). It is questionable that serum lactate can be used as a predictor factor for a surgeon for making decision whether the gastric perforation in septic condition should be repaired or not. In septic shock condition it is risky for the surgeon to repair the gastric perforation because it will become reperforated, instead the surgeon just only makes a minimal surgery by inserting a tube to drain and decompress the abdominal cavity. Lactate can be used as a marker of global tissue ischemia and the increase level in serum is also in line with the level of the intestinal hypoperfusion (Lee \& Suk An 2016, Hirst et al 2013). Lactate is also used in Surviving Sepsis Campaign as an indicator of the adequacy of resuscitation in management of sepsis (Su \& Won 2016). Furthermore, lactate serum can be used to measure the severity of sepsis, the severity of organ failure, the length of stay of septic patients and as the mortality predictor (Lee \& Suk An 2016, Glatter \& Winters 2009).

\section{MATERIALS AND METHODS}

Forty six patients diagnosed as gastric perforation and was operated who came to Dr. Soetomo Hospital from October 2014 to October 2015 were recuited as samples, samples were taken consequtively in one year. Serum lactate was taken one hour before repairing the perforation. After being repaired, the patients were observed until the 14th day to evaluate whether any reperforation would occur or not. The design of this research was cross-sectional analitic observational study, the data was analyzed using independent t-test, cross tabulation analysis and ROC for obtaining the cutoff point as a predictor of the reperforation after the gastric perforation was repaired. The inclusion criteria in this study were age between 20-80 years, gastric perforation are located on the anterior wall, caused by peptic ulcer disease, BMI $=18.5 \mathrm{~kg} / \mathrm{m} 2$, no systemic diseases, which influence the lactate metabolism, and repairing gastric perforation using the standard CellanJones technique. Whereas, the exclusion criteria were reperforated patients who refused to be reoperated and the initial biopsy from the edge of the perforation was malignancy.

\section{RESULTS}

Between October 2014 and October 2015, 46 patients diagnosed with generalized peritonitis caused by gastric ulcer perforation repaired using Cellan-Jones technique were included in this study. There were 40 male $(87.0 \%)$ and 6 female $(13.0 \%)$ (Table 1$)$.

\section{Gender and age}

Table 1. Gender

\begin{tabular}{ccc}
\hline Gender & Frequency & $\%$ \\
\hline Male & 40 & 87.0 \\
Female & 6 & 13.0 \\
Total & 46 & 100.0 \\
\hline
\end{tabular}

The median age was $60.46 \pm 10,10$ years (range: $40-80$ years). The age of male patients was $60.28 \pm 10.39$ and female was $61.67 \pm 8.66$ (table 2)

Tabel 2. Age of patients gastric perforation

\begin{tabular}{lccc}
\hline \multicolumn{1}{c}{ Gender } & $\mathrm{n}$ & $\overline{\mathrm{x}} \pm \mathrm{SD}$ & Min - Max \\
\hline Male & 40 & $60.28 \pm 10.39$ & $40-80$ \\
Female & 6 & $61.67 \pm 8.66$ & $53-77$ \\
Total & 46 & $60.46 \pm 10.10$ & $40-80$ \\
\hline
\end{tabular}

Out of 46 patients, reperforation occurs in $32(69.6 \%)$ patients, non-reperforation in $14(30.4 \%)$ patients (table 3)

\section{Reperforation case}

Tabel 3. Frequency of reperforation

\begin{tabular}{lcc}
\hline \multicolumn{1}{c}{ Reperforation } & Frequency & $\%$ \\
\hline Non-reperforation & 32 & 69.6 \\
Reperforation & 14 & 30.4 \\
Total & 46 & 100.0 \\
\hline
\end{tabular}

\section{Onset of reperforation}

Median onset of reperforation was detected on day-5, the earliest was detected on day-4 and the latest on day8 (table 4)

Tabel 4. Onset of reperforation

\begin{tabular}{ccc}
\hline Onset of reperforation & Frequency & $\%$ \\
\hline Day-4 & 4 & 28.6 \\
Day-5 & 4 & 28.6 \\
Day-6 & 5 & 35.7 \\
Day- 8 & 1 & 7.1 \\
Total & 14 & 100.0 \\
\hline
\end{tabular}




\section{Level of lactate}

Mean of lactate level patients with gastric perforation in this study were $2.92 \pm 0.90 \mathrm{mmol} / \mathrm{L}$. The lowest of lactate level was $1.2 \mathrm{mmol} / \mathrm{L}$ and the highest 4.4 $\mathrm{mmol} / \mathrm{L}$, Mean of lactate level in non-reperforation case was $2.60 \pm 0.76 \mathrm{mmol} / \mathrm{L}$ and in reperforation case 3.74 $\pm 0.59 \mathrm{mmol} / \mathrm{L}$ (Table 5).

Using independent t-test, there was significant difference between lactate level in patients with reperforation compared with that of non-reperforation patients $(\mathrm{p}=0.000)$. With ROC curve analysis, the cutoff point of lactate level for reperforation was 3.35 mmol/L with AUC area 0.902 (Fig. 1).

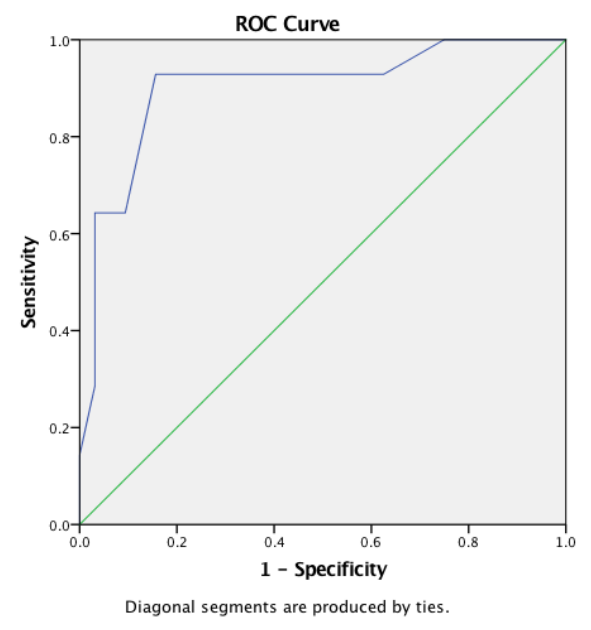

Fig. 1. ROC analysis between lactate level and reperforation.
Based on the cut off point obtained $(3.35 \mathrm{mmol} / \mathrm{L})$, the distribution of prediction of reperforation compared with non-reperforation as stated on Table 6.

Based on tabel 6 above, the diagnostic value of lactate level with the cut off $3.35 \mathrm{mml} / \mathrm{L}$ as follow: sensitivity $=92.9 \%$, specificity $=84.4 \%$, positive predictive value $=72.2 \%$, negative predictive value $=96.4 \%$, likelihood ratio $(+)=5.955$, likelihood ratio $(-)=0.084$, and accuracy $=87.0 \%$.

\section{DISCUSSION}

In this study BMI (Body Mass Index) was determined obove or equal to $18.5 \mathrm{~kg} / \mathrm{m} 2$, it was aimed to avoid the disturbance of post-repaired wound healing in undernutrition patients (Molnar et al 2014). The patinents who have systemic disease were also not included in this study because the disease influenced the wound healing process and lactate metabolism (Thomas \& Cathy 2011). Gastric perforation caused by malignancy was excluded from this study because of the changes of wound healing process in malignancy (Howard et al 2004). In perforated gastric ulcer perforation, leakage of gastric content into the peritoneal cavity causes generalized peritonitis, sepsis and furthermore septic shock if it is not treated perfectly (Hyman et al 2009) (Wagner \& Egger 2003). The lack ability of the tissue to use oxygen in septic condition makes the tissue healing process of the just-repaired perforated wound will be interfered, it is at risk for post operative reperforation (Sommer \& 2013).

Tabel 5. Mean of lactate level in reperforation case

\begin{tabular}{lcccc}
\hline \multicolumn{1}{c}{ Reperforation } & $\mathrm{n}$ & $\begin{array}{c}\overline{\mathrm{x}} \pm \mathrm{SD} \\
(\mathrm{mmol} / \mathrm{L})\end{array}$ & $\begin{array}{c}\text { Min }-\mathrm{Max} \\
(\mathrm{mmol} / \mathrm{L})\end{array}$ & $\mathrm{p}$ \\
\hline Non-reperforation & 32 & $2.60 \pm 0.76$ & $1.2-4.2$ & \\
Reperforation & 14 & $3.74 \pm 0.59$ & $2.1-4.4$ & 0.000 \\
Total & 46 & $2.92 \pm 0.90$ & $1.2-4.4$ & \\
\hline
\end{tabular}

Tabel 6. Cut off point of lactate level $3.35 \mathrm{mmol} / \mathrm{L}$ and prediction of reperforation

\begin{tabular}{lccc}
\hline \multicolumn{1}{c}{ Prediction } & \multicolumn{2}{c}{ Reperforation case } & \multirow{2}{*}{ Total } \\
\cline { 2 - 3 } & Reperforation & Non-reperforation & \\
\hline *Reperforation (Lactate & 13 & 5 & 18 \\
$\begin{array}{l}\text { *3.35 mmol/L) } \\
\text { *Non-reperforation (Lactate }\end{array}$ & 1 & & \\
$\begin{array}{l}\text { <3.35 mmol/L) } \\
\text { *Total }\end{array}$ & 14 & 27 & 28 \\
\hline
\end{tabular}


The increase of serum lactate level is the sign of tissue hypoxia, and it can be used as a marker to predict the success rate of the tissue repair (Bakker et al 2000) (Marik \& Bellomo 2013). The mortality rate is $27 \%$ when there is no reperforation after repair (Hemmat \& Alireza 2011), however the mortality rate will increase another 29.4\% higher if it is reperforated (Møller \& Hylander 2008). So, the surgeon needs a decision whether the gastric perforation in septic condition should be directly repaired or not, because it will become reperforated because of the impaired tissue healing, instead the surgeon just only makes a minimal surgery by inserting a tube to drain and decompress the abdominal cavity while waiting the resuscitation process.

The repair of perforated gastric ulcer in this study used omental-patch repair method with omentopexy technique (Cellan-Jones technique). Three or 4 seromuscolar stitches were passed through the normal tissue at both sides of the perforated hole, without pulling both sides closer, omentum together with its pedicle was used as a graft and plug the hole, and then the stitches from both sides were knotted together without tension to keep the omentum being in place (Mariëtta et al 2010) (Cellan-Jones 1929). Nasogastric tube was maintained after repairing to prevent gastric dilatation (Tanguy et al 2007). The role of omentum in this case was to stimulate fibrin formation, then collagen tissue will be formed closing the perforation hole permanently (Sommer et al 2013). The third generation of cephalosporin and proton pump inhibitor were given in all the cases beginning preoperatively. There was a significant difference in the mean of the lactate level in the group with reperforation compared with that of the non-reperforation group, that is as big as $3.74 \pm 0.59 \mathrm{mmol} / \mathrm{L}$ and $2.60 \pm 0.76 \mathrm{mmol} / \mathrm{L}$. Using ROC curve analysis, there was the cut-off point of lactate level for reperforation $3.35 \mathrm{mmol} / \mathrm{L}$, with sensitivity $92.9 \%$, specificity $84.4 \%$, positive predictive value $72 \%$ and negative predictive Value $96.4 \%$, accuracy $87.0 \%$ and in the AUC value 0.902 .

\section{CONCLUSION}

There was a significant difference in the mean of the lactate level in the group with reperforation compared with that of non-reperforation group, that was as big as $3.74 \pm 0.59 \mathrm{mmol} / \mathrm{L}$ and $2.60 \pm 0.76 \mathrm{mmol} / \mathrm{L}$. The cut-off point of lactate level $3.35 \mathrm{mmol} / \mathrm{L}$ as a predictor factor for reperforation after repairing gastric perforation, with sensitivity $92.9 \%$, specificity $84.4 \%$, positive predictive value $72.2 \%$ and negative predictive value $96.4 \%$ and accuracy $87.0 \%$.

\section{ACKNOWLEDGMENT}

The authors declare that there is no financial or nonfinancial conflicts of interest related to the subject matter or materials discussed in the manuscript.

\section{REFERENCES}

Bakker J, Schieveld SJ, Brinkert W (2000). Serum lactate level as an indicator of tissue hypoxia in severely ill patients. Ned Tijdschr Geneeskd 144, 377-83

Cellan-Jones CJ (1929): A rapid method of treatment in perforated duodenal ulcer. BMJ, 1076-1077

Chung K, Vishalkumar G (2017). Perforated peptic ulcer - an update, World J Gastrointest Surg 27, 1-12

Glatter RD, Winters ME (2009), What is the clinical utility of obtaining serum lactate and arterial base deficit values in patients with early signs of sepsis and septic shock? Medscape

Hemmat M, Alireza (2011). Generalized peritonitis requiring re-operation after leakage of omental patch repair of perforated peptic ulcer. Saudi J Gastroenterol $17,124-128$

Hirst NA, Tiernan J, Millner P (2013). Systematic review of methods to predict and detect anastomotic leakage in colorectal surgery. Colorectal Disease 16, 95-109

Howard Y, Julie B, Ash A, et al (2004). Gene expression signature of fibroblast serum response predicts human cancer progression similarities between tumors and wounds. Plos Biology 2, 0206

Hyman N, Cataldo O, Burns E, Shackford S (2009). Anastomotic leaks after Bowel Resection: What does peer review teach us about the relationship to postoperative mortality? J Am Coll Surg J 208, 48-52

Lee S, Suk An W (2016). New clinical criteria for septic shock: serum lactate level as new emerging vital sign, J Thorac Dis 8, 1388-1390

Mariëtta J. Bertleff J. Lange B (2010). Perforated peptic ulcer disease: A review of history and treatment. Dig Surg 27, 161-169

Marik PE, Bellomo R (2013). Lactate clearance as a target of therapy in sepsis: A flawed paradigm. OA Crit Care 1, 3

Møller, Hylander M (2008). Sepsis in patients with peptic ulcer perforation - An identification of risk factors in patients surgically treated for peptic ulcer perforation: 12AP3-4, European Journal of Anaesthesiology 25, 170

Molnar J, Mary J, Clark W (2014). Nutrition and chronic wounds. Advances in Wound Care 3, 663

Sommer K, Sander A, Albig M (2013). Delayed wound repair in sepsis is associated with reduced local proinflammatory cytokine expression. PLOS ONE 8 
Su M, Won S (2016). New clinical criteria for septic shock: serum lactate level as new emerging vital sign, J Thorac Dis 8, 1388-1390

Tanguy M, Seguin P, Yannick M (2007). Bench-tobedside review: Routine postoperative use of the nasogastric tube - utility or futility? Critical Care 11, 201
Thomas H, Cathy B (2011). Checklist for factors affecting wound healing advances. Skin \& Wound Care 24, 192

Vikram K (2018). Intestinal Anastomosis. Medscape Updated

Wagner O, Egger B.(2003). Influential factors in anastomosis healing. Swiss Surg 9, 105-13 